\title{
ASSESSMENT OF HAEMOGLOBIN A1C EVOLUTION USING TWO STATISTICAL APPROACHES (SURVIVAL ANALYSIS AND LINEAR REGRESSION) IN PERSONS WITH DIABETES MELLITUS
}

\author{
Katerina Langova $^{a *}$, Helena Pribylova ${ }^{\mathrm{b}, \mathrm{c}}$, Marketa Kajabova ${ }^{\mathrm{d}}$, Jiri Luza ${ }^{\mathrm{b}}$ \\ a Department of Biophysics, Faculty of Medicine and Dentistry, Palacky University Olomouc, Czech Republic \\ ${ }^{b}$ Department of Physiology, Faculty of Medicine and Dentistry, Palacky University Olomouc \\ c Department of Nursing, Faculty of Health Sciences, Palacky University Olomouc \\ ${ }^{d}$ Department of Clinical Biochemistry, University Hospital Olomouc \\ e-mail: langova@tunw.upol.cz
}

Received: September 7, 2008; Accepted (with revision): December 12, 2008

Key words: Survival analysis/Linear regression/Haemoglobin Alc/Continuous glucose monitoring/Diabetes mellitus

Background: Intensive selfmonitoring is an important and cost-demanding part of diabetes treatment. Continuous glucose monitoring (CGM) using transcutaneous sensors offers "real time" information on glycemia. In the present study, we assessed the therapeutic efficacy of CGM on metabolic control using two different statistical methods: linear regression and "survival analysis".

Objectives: (1) to assess the therapeutic efficacy of CGM on metabolic control using two different statistical methods: linear regression and survival analysis; (2) to demonstrate the particular advantages of each statistical method.

Methods: A total of 42 persons with diabetes mellitus treated by means of an insulin pump participated in this study. According to the means of selfmonitoring persons with diabetes were divided into two groups: 1 . intervention group of 17 persons using CGM, 2. control group of 25 persons using a glucometer. Each person was followed for a period of three months. At the beginning of the study and at the end of each month HbA1c was determined.

Results: Both the regression analysis and survival analysis brought evidence of significant changes of the HbA1c in either of the groups. The method of linear regression enables to analyse the evolution of HbA1c in each individual person followed by comparison of the groups. The survival analysis demonstrated that the probability of HbA1c decrease to the predefined level as well as its further maintaining at this level was higher in the CGM group. The mean time interval necessary to $\mathrm{HbA1c}$ decrease was shorter in the CGM group.

Conclusions: The efficacy of CGM was demonstrated. In addition to linear regression, survival analysis appears to be an useful complementary method in the statistical evaluation of the treatment efficacy.

\section{INTRODUCTION}

Intensive selfmonitoring is an important and costly part of diabetes treatment ${ }^{5,17,19,29}$, particularly in persons using insulin pumps ${ }^{27}$. In recent years, continuous glucose monitoring (CGM) with transcutaneous sensors, transmitters and monitors has become a sophisticated approach offering "real time" information on glycemia. Several studies have shown the effectiveness of $\mathrm{CGM}^{2,6}$. However, the benefits, hazards, accuracy, reliability and clinical applicability of $\mathrm{CGM}^{6,12,13}$ need to be re-established using both case reports and appropriate statistical methods even though recent trials demonstrate that interstinal fluid glucose and blood glucose concentrations could be made identical by resorting to algorithmus based on concurrent blood glucose levels alone ${ }^{20}$.

Since 2002 we have done statistical analyses for a number of clinical studies on diabetes ${ }^{(7-13,21,23-26)}$. The glycaemic profiles and haemoglobin A1c were evaluated as parameters of diabetes control indicating the success of treatment. Concentration of haemoglobin A1c highly correlates with the mean plasma glucose concentration.
Various statistical methods but survival analysis were applied according to the analyzed data and objectives of the respective study.

Linear regression is a form of regression analysis in which the relationship between one or more independent variables and another variable (dependent variable), is modelled by a special function, namely, linear regression equation ${ }^{1}$.

Survival analysis is a set of statistical methods which evaluate the time interval from the beginning of the observation until the occurrence of a certain event. Generally, this time interval is called the survival interval (although it does not need to identify the survival of a patient). The survival interval identifies the number of years, months, weeks or days from the beginning of the observation until the occurrence of a defined event.

Most studies are complete before the observed event occurs for all subjects. This situation is in survival analysis described as "censoring".

An example of such event would be the achievement of a certain level of diabetes compensation. Survival analysis was first described by Kaplan and Meier 
in $1958^{14,15}$ and was used to evaluate the survival time of oncological patients. This statistical method has been mostly used in epidemiological studies ${ }^{3,4,16,22,28}$.

In the present study, in order to describe the therapeutic effects of continuous glucose monitoring on metabolic control (i.e. mean plasma glucose concentrations over the last 2-3 months represented by HbA1c concentrations) two different statistical methods were applied: 1) the widely used linear regression analysis and 2) the survival analysis of data which has not been routinely used for this purpose ${ }^{26}$.

The objective of this study was (1) to assess the therapeutic efficacy of CGM on metabolic control using two different statistical methods: linear regression and survival analysis, and (2) to demonstrate the particular advantages of each statistical method applied.

\section{METHODS}

The data in this statistical analysis were gathered at The Faculty of Medicine and Dentistry, Palacky University Olomouc and the University Hospital Olomouc since the year 2006 until the year 2008. Each subject was followed in the outpatient clinic for a period of three months. $\mathrm{HbA} 1 \mathrm{c}$ was assesed at the beginning $\mathrm{HbA}_{1 \mathrm{c}}$ land at the end of each month $\left(\mathrm{HbA}_{1 \mathrm{c}} 2, \mathrm{HbA}_{1 \mathrm{c}} 3, \mathrm{HbA}_{1 \mathrm{c}} 4\right)$.

\section{Study subjects}

Two independent groups of persons with diabetes mellitus were followed (Table 1):

1. An intervention group of 17 persons with diabetes using transcutaneous sensors, 11 men and 6 women, aged 19-69 years, (mean 44.9 years, SE 4.0).
2. A control group of 25 persons with diabetes using a glucometer, 13 men and 12 women, aged 24-66 years (mean 44.9 years, SE 2.9).

\section{Determination of Haemoglobin Alc}

The HbAlc concentration in blood was determined using the sophisticated HPLC procedure in the Department of Clinical Biochemistry, University Hospital Olomouc (Table 2).

Principles of the HbA1c estimation. The analyzer PDQ Plus employs the principles of boronate affinity and high-performance liquid chromatography (HPLC). Glycated proteins (haemoglobins and plasma proteins) differ from non-glycated proteins by the attachment of sugar moiety to the former at various binding sites by means of a ketoamine bond. GHb and GPP thus contain 1,2-cis-diol groups not found in non-glycated proteins. These diol groups provide the basis for separation of glycated and non-glycated components by boronate afinity chromatography. In this analytical technique, a boronate is bonded to the surface of the column support. When a solution of proteins is passed through the column, the glycated component is retained by the complexing of its diol groups with the boronate. After the unretained nonglycated component elutes from the column, the glycated component is eluted from the column with a reagent that displaces it from the boronate. Both components are detected spectrofotometrically at $413 \pm 2 \mathrm{~nm}$.

Parameters of reliability. Limit of quantitation: $3.0 \%$, Linearity: up to $19.5 \%$

Repeatability (within-run imprecision): $1.4 \%$. Reproducibility (between-run imprecision): $1.4 \%$. Reference range for normal population: 2.8 to $4.0 \%$.

Table 1. Characteristics of the intervention (CGM) and of the control group.

\begin{tabular}{|l|c|c|c|}
\hline Group & CGM & Control & Significance $(P)$ \\
\hline $\mathrm{N}$ & 17 & 25 & \\
\hline Male/Female & $11 / 6$ & $13 / 12$ & 0.414 \\
\hline Age (mean \pm SE) [years] & $44.9 \pm 4.0$ & $44.9 \pm 2.6$ & 0.996 \\
\hline Age range [years] & $19-69$ & $24-66$ & \\
\hline Duration of diabetes (mean \pm SE) [years] & $17.8 \pm 2.9$ & $15.4 \pm 2.0$ & 0.482 \\
\hline Duration of diabetes range [years] & $1-45$ & $2-43$ & \\
\hline
\end{tabular}

Table 2. Evaluation of metabolic control in persons with diabetes according to HbAlc concentration in blood.

\begin{tabular}{|l|c|c|}
\hline \multicolumn{1}{|c|}{ Metabolic control in diabetes } & $\begin{array}{c}\text { Calibration according to DCCT } \\
\text { (valid before 1. 1. 2004) }\end{array}$ & $\begin{array}{c}\text { Calibration according to IFCC } \\
\text { (valid since 1. 1. 2004) }\end{array}$ \\
\hline Excellent & $<6.5 \%$ & $<4.5 \%$ \\
\hline Satisfactory & $6.5-7.5 \%$ & $4.5-6.0 \%$ \\
\hline Unsatisfactory & $>7.5 \%$ & $>6.0 \%$ \\
\hline
\end{tabular}




\section{Statistical Analysis}

The Program SPSS v.15,0, SPSS, Inc., Chicago, IL, USA was used in the statistical analysis.

First, the method of regression analysis was used to evaluate the development of the HbAlc values in the course of three months. In each subject, regression coefficient was calculated in order to describe the evolution of HbA1c (see Table $3 \mathrm{a}$ and Table $3 \mathrm{~b}$ ). Two samples ttest was applied to compare the regression coefficients of subjects in the intervention and in the control group. Second, the method of survival analysis was applied to evaluate the same data. The survival analysis was aimed at the occurrence of the followed events in time in subjects in both of the groups.

A total of 8 various events was empirically defined, and analyzed:

1. first decrease of HbA1c below the $5 \%$ value determined in the laboratory,

2. maintained decrease of $\mathrm{HbA} 1 \mathrm{c}$ below the $5 \%$ laboratory value in two consecutive controls,

3 . first decrease of $\mathrm{HbA} 1 \mathrm{c}$ by at least $3 \%$ from the baseline (this event was defined considering the reliability, repeatibility and reproducibility of $\mathrm{HbA} 1 \mathrm{c}$ determination),

4. maintained decrease of HbAlc by at least $3 \%$ from the baseline in two consecutive controls,

5. first decrease of $\mathrm{HbA} 1 \mathrm{c}$ by at least $5 \%$ from the baseline (this event was defined empirically),

6. maintained decrease of $\mathrm{HbA} 1 \mathrm{c}$ by at least $5 \%$ from the baseline in two consecutive controls,

7. first decrease of $\mathrm{HbAlc}$ by at least $10 \%$ from the baseline (this event was defined empirically),

8. maintained decrease of $\mathrm{HbA} 1 \mathrm{c}$ by at least $10 \%$ from the baseline in two consecutive controls.

The aim of the survival analysis was to determine the probability of $\mathrm{HbA} 1 \mathrm{c}$ decrease below an empirically defined value over time. For the graphic representation of the probability of the HbAlc decrease below the defined value the Kaplan-Meier curve presenting one minus "survival function" was used. The final curve is of ascending character which is the optic equivalent for increasing probability in the course of time.

The statistical significance of differences between survival curves in the control and intervention group was evaluated by means of log-rank test. $P<0.05$ was considered significant.

\section{RESULTS}

\section{Linear regression analysis (Fig. 1)}

In the intervention group, the mean regression coefficient was -0.246 (the negative value demonstrates a decrease of $\mathrm{HbA} 1 \mathrm{c}$ in the course of the observational period), SD 0.395 , range from -1.24 to 0.47 . In the control group the mean regression coefficient was 0.138 (positive value demonstrates an increase of $\mathrm{HbA} 1 \mathrm{c}$ in the course of the observational period), SD 0.248 , range from -0.46 to 0.72 . Two samples t-test

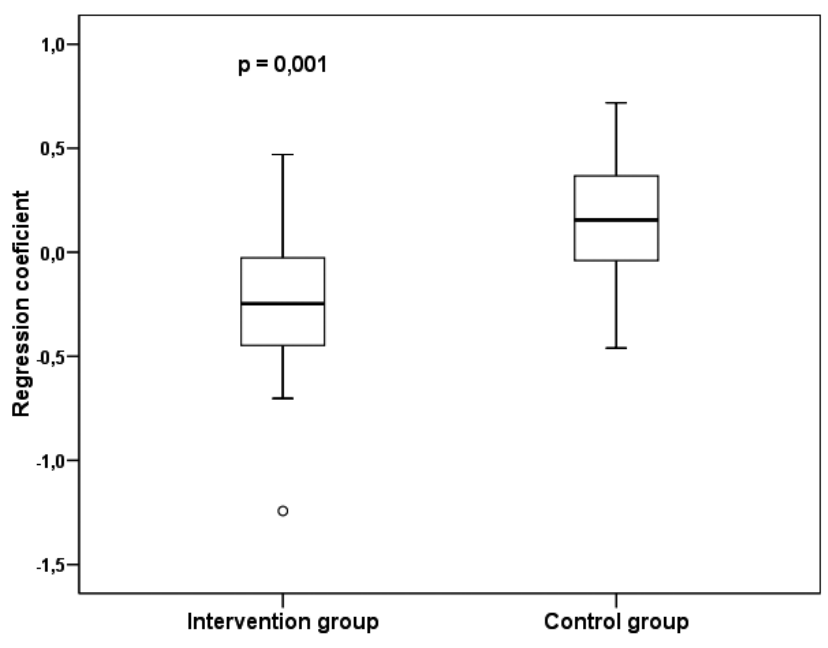

Fig. 1. Regression analysis: Distribution of regression coefficients in the intervention $(n=17)$ and control group $(n=25)$. P-significance of difference (two samples t-test between both groups).

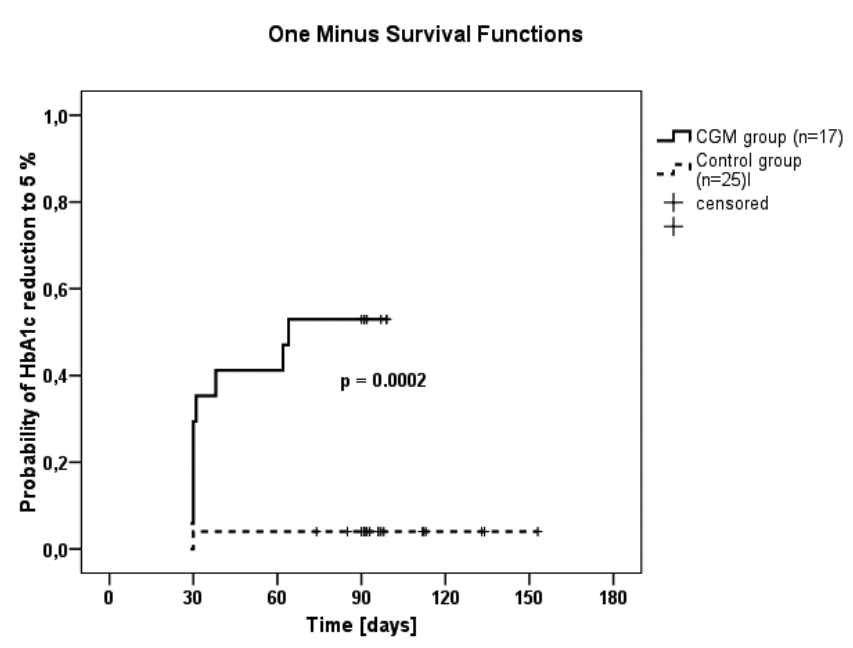

Fig. 2. Survival analysis: Kaplan-Meier curve showing the probability of the first decrease of HbAlc below the $5 \%$ value determined in the laboratory in the intervention (CGM) and control group. $P$ - significance of difference (log-rank test).

revealed a significant difference between the mean regression coefficients $(p=0.001)$. See box graph in Fig. 1 .

Survival analysis (Fig. 2, Fig. 3 and Table 4).

The probability of HbAlc decrease below the defined value ( $5 \%$ ) and the probability of maintaining the decrease in at least two consecutive controls is shown in Kaplan - Meier curves in Fig. 2-3. The estimates of mean time interval until the decrease below the defined value for both intervention and control group and the significance of the log-rank test are shown in Table 4. A significant difference between the intervention and the control group was shown in all defined events. The mean time interval until the HbAlc decrease was proved to be significantly shorter in the intervention group. 


\section{DISCUSSION}

Linear regression analysis and survival analysis are two methods evaluating the development of change in an independent manner. While linear regression enables the assesment of change in a complete time interval, survival analysis expresses the probability of occurrence of an expected event. Currently, survival analysis is mainly used in epidemiological studies which follow mortality. Recently the role of $\mathrm{HbAlc}$ as a risk factor for heart failure in persons with diabetes was assessed using the survival function ${ }^{22}$. Our aim was to point out the possibility of survival analysis application in clinical studies which follow therapeutic efficiency.

In our study, in the intervention group the negative value of regression coefficient appeared in 13 of 17 persons with diabetes ( $76 \%$ ) showing a decrease of HbAlc. On the other hand, in the control group the negative value of regression coefficient appeared only in 8 of 25 persons ( $32 \%$ ). So, using two samples t-test a significant diference between the distribution of regression coefficients in both groups was demonstrated.

Survival analysis shows the decrease of HbA1c below the defined values in the intervention group using CGM in the course of three months. Fig. 2 and 3 shows that
One Minus Survival Functions

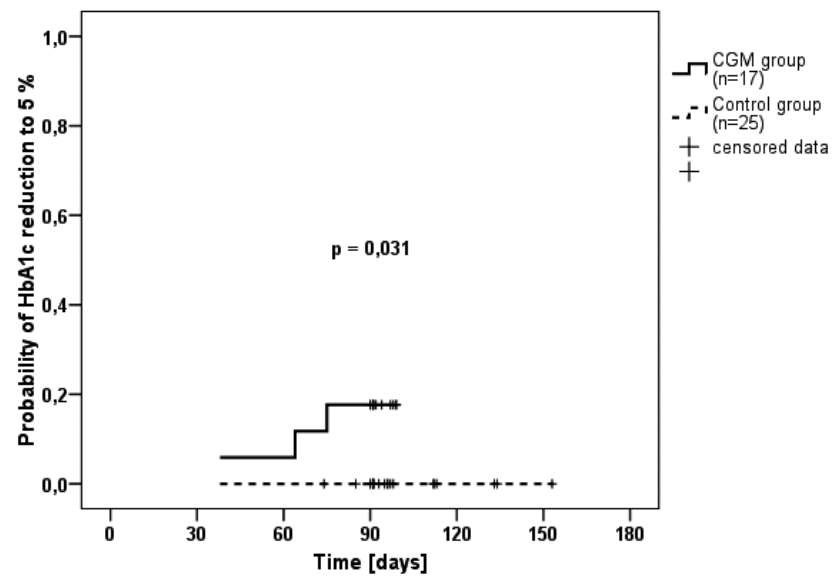

Fig. 3. Survival analysis: Kaplan-Meier curve showing the probability of maintained decrease of $\mathrm{HbAlc}$ below the $5 \%$ laboratory value in two consecutive controls in the intervention (CGM) and control group. $P$ - significance of difference (log-rank test).

Table 3a. Intervention group: Evoluation of HbAlc from the introduction of CGM (HbA1c 1) to the end $3^{\text {rd }}$ month (HbAlc 4).

\begin{tabular}{|c|c|c|c|c|c|c|c|}
\hline Patient No & Age $[y]$ & $\begin{array}{c}\text { Diabetes } \\
\text { duration } \\
{[\mathrm{y}]}\end{array}$ & $\begin{array}{c}\mathrm{HbA1c} \\
1 \\
{[\%]}\end{array}$ & $\begin{array}{c}\mathrm{HbA} 1 \mathrm{c} \\
2 \\
{[\%]}\end{array}$ & $\begin{array}{c}\mathrm{HbA} 1 \mathrm{c} \\
3 \\
{[\%]}\end{array}$ & $\begin{array}{c}\text { HbA1c } \\
4 \\
{[\%]} \\
\end{array}$ & $\begin{array}{l}\text { Regression } \\
\text { coefficient }\end{array}$ \\
\hline 1 & 31 & 19 & 8.7 & 5.9 & 5.3 & 6.6 & -0.70 \\
\hline 2 & 27 & 10 & 8.6 & 6.4 & 7.5 & 7.2 & -0.25 \\
\hline 3 & 64 & 37 & 6.1 & 4.8 & 5.5 & 4.7 & -0.31 \\
\hline 4 & 62 & 1 & 5.8 & 3.9 & 3.6 & 3.7 & -0.49 \\
\hline 5 & 53 & 18 & 6.7 & 10.1 & 6.5 & 6.2 & -0.45 \\
\hline 6 & 48 & 26 & 6.5 & 5.4 & 5.2 & 5.6 & -0.28 \\
\hline 7 & 65 & 12 & 5.7 & 5 & 5.1 & 5.5 & -0.05 \\
\hline 8 & 32 & 23 & 6.5 & 6.2 & 5.1 & 5.6 & -0.38 \\
\hline 9 & 60 & 1 & 5.9 & 5.2 & 4.7 & 6 & -0.03 \\
\hline 10 & 35 & 26 & 5.2 & 4.2 & 5.4 & 5.4 & 0.18 \\
\hline 11 & 51 & 19 & 6.4 & 4.8 & 6 & 5.6 & -0.10 \\
\hline 12 & 40 & 26 & 11.9 & 10 & 9.4 & 7.9 & -1.24 \\
\hline 13 & 69 & 10 & 9.3 & 8.4 & 9.9 & 9.8 & 0.09 \\
\hline 14 & 24 & 12 & 5.2 & 4.8 & 5.6 & 7.2 & 0.47 \\
\hline 15 & 27 & 11 & 5.6 & 4.7 & 4.2 & 5.3 & -0.12 \\
\hline 16 & 57 & 45 & 6.3 & 5.1 & 3.9 & 4.6 & -0.62 \\
\hline 17 & 19 & 7 & 8.3 & 6.8 & 8.5 & 8 & 0.08 \\
\hline mean $\pm S E$ & $\begin{array}{r}44.9 \\
\pm 16.5 \\
\end{array}$ & $\begin{array}{r}17.8 \\
\pm 11.9\end{array}$ & $\begin{array}{r}7.0 \\
+1.8\end{array}$ & $\begin{array}{r}6.0 \\
\pm 1.9\end{array}$ & $\begin{array}{r}6.0 \\
\pm 1.8\end{array}$ & $\begin{array}{r}6.2 \\
\pm 1.5\end{array}$ & $\begin{array}{r}-0.25 \\
\pm 0.40\end{array}$ \\
\hline
\end{tabular}



in persons with diabetes mellitus

Table 3b. Control group: Evoluation of HbA1c without CGM from beginning of the study (HbA1c 1) to the end $3^{\text {rd }}$ month (HbAlc 4).

\begin{tabular}{|c|c|c|c|c|c|c|c|}
\hline Patient $N_{0}$ & Age [y] & $\begin{array}{c}\text { Diabetes } \\
\text { duration } \\
{[y]}\end{array}$ & $\begin{array}{c}\text { HbAlc } \\
1 \\
{[\%]}\end{array}$ & $\begin{array}{c}\mathrm{HbA} 1 \mathrm{c} \\
2 \\
{[\%]}\end{array}$ & $\begin{array}{c}\mathrm{HbA} 1 \mathrm{c} \\
3 \\
{[\%]}\end{array}$ & $\begin{array}{c}\mathrm{HbA} 1 \mathrm{c} \\
4 \\
{[\%]}\end{array}$ & $\begin{array}{l}\text { Regression } \\
\text { coefficient }\end{array}$ \\
\hline 1 & 27 & 6 & 5.8 & 4.2 & 5.4 & 5.2 & -0.04 \\
\hline 2 & 53 & 6 & 6.9 & 5.7 & 5.6 & 5.7 & -0.34 \\
\hline 3 & 42 & 32 & 7.5 & 6.5 & 7.6 & 8.6 & 0.37 \\
\hline 4 & 53 & 17 & 6.2 & 5.6 & 6.9 & 6.3 & 0.16 \\
\hline 5 & 58 & 6 & 11.4 & 10.2 & 12.3 & 12 & 0.39 \\
\hline 6 & 48 & 27 & 6.3 & 5.8 & 6.5 & 6.7 & 0.19 \\
\hline 7 & 48 & 3 & 6.8 & 6.9 & 9 & 7.9 & 0.53 \\
\hline 8 & 58 & 5 & 7.1 & 5.5 & 6.9 & 7.1 & 0.16 \\
\hline 9 & 46 & 12 & 9 & 11 & 9.8 & 9.6 & 0.07 \\
\hline 10 & 27 & 10 & 6.6 & 8 & 6.8 & 7.2 & 0.06 \\
\hline 11 & 66 & 13 & 10.1 & 12.7 & 12.6 & 12.6 & 0.72 \\
\hline 12 & 24 & 22 & 8.8 & & 7.5 & 7.5 & -0.46 \\
\hline 13 & 41 & 8 & 10.2 & 10.4 & 10.9 & 11.4 & 0.40 \\
\hline 14 & 35 & 11 & 6.2 & & 6.2 & 6.8 & 0.16 \\
\hline 15 & 34 & 20 & 6.4 & 7.2 & 7.3 & 6.8 & 0.13 \\
\hline 16 & 55 & 20 & 6.3 & 7.6 & 8 & 7.8 & 0.41 \\
\hline 17 & 62 & 14 & 6.2 & 7.4 & 7.7 & 5.6 & -0.17 \\
\hline 18 & 56 & 17 & 6.5 & 8.3 & 8.6 & 8.1 & 0.50 \\
\hline 19 & 43 & 17 & 7.1 & 7.6 & 7.4 & 7.1 & 0.01 \\
\hline 20 & 31 & 22 & 6.6 & 5.8 & 6 & 6.4 & -0.03 \\
\hline 21 & 54 & 2 & 5.9 & 6 & 5.6 & 5.3 & -0.21 \\
\hline 22 & 24 & 10 & 5 & 5.5 & 5.5 & 6.3 & 0.26 \\
\hline 23 & 33 & 10 & 8.5 & 7.5 & 8.7 & & -0.05 \\
\hline 24 & 63 & 43 & 6.6 & 6.4 & 6.3 & 6.4 & -0.10 \\
\hline 25 & 42 & 32 & 7.5 & 6.5 & 7.6 & 8.6 & 0.37 \\
\hline mean $\pm S E$ & $\begin{array}{r}44.9 \\
\pm 12.9\end{array}$ & $\begin{array}{r}15.4 \\
\pm 10.1\end{array}$ & $\begin{array}{r}7.3 \\
\pm 1.6\end{array}$ & $\begin{array}{r}7.3 \\
\pm 2.1\end{array}$ & $\begin{array}{r}7.7 \\
\pm 2.0\end{array}$ & $\begin{array}{r}7.6 \\
\pm 2.0\end{array}$ & $\begin{array}{r}0.14 \\
\pm 0.28\end{array}$ \\
\hline
\end{tabular}

the probability of this change is significantly higher in the intervention group than in the control group. The same applies on all other criteria of $\mathrm{HbAlc}$ decrease which we have defined pragmatically. It is evident that the probability of maintaining a longer lasting HbAlc decrease is below the defined value for at least until the next control (one month) is smaller than the probability of achieving at least one $\mathrm{HbAlc}$ value below the defined value (Fig. 2 vs. Fig. 3). Table 4 shows that the HbAlc decrease is achieved significantly sooner in the intervention group in comparison to the control group. The results of survival analysis show (similarly as the slopes-analysis in individual subjects using regression analysis) the positive effect of CGM on $\mathrm{HbAlc}$ values which is in accordance with conclusions of various studies using other statistical methods such as paired t-test etc.

\section{CONCLUSIONS}

We can conclude that CGM is an effective tool to improve diabetes control. In addition to linear regression survival analysis has proven to be an useful method complementing other statistical methods used for evaluation of the treatment efficacy for diabetes. It may be applied in situations with fluctuating therapeutic outcomes with alternative remissions and relapses. 
Table 4. Mean time elapsed ( \pm standard error) until the HbAlc reduction to the defined target level.

\begin{tabular}{|l|c|c|c|}
\hline \multicolumn{1}{|c|}{ Defined target level of $\mathrm{HbA}_{1} \mathrm{c}$} & $\begin{array}{c}\text { CGM group } \\
\text { [days] }\end{array}$ & $\begin{array}{c}\text { Control group } \\
\text { [days] }\end{array}$ & $\begin{array}{c}\text { Significance } \mathrm{P} \\
\text { (log-rank test) }\end{array}$ \\
\hline$<=5 \%$ at first occasion & $66.8 \pm 7.7$ & $148.1 \pm 4.8$ & 0.0002 \\
\hline$<=5 \%$ at two sequential occasion & $91.9 \pm 4.0$ & $*$ & 0.031 \\
\hline $\begin{array}{l}<=3 \% \text { of the start value } \\
\text { at first occasion }\end{array}$ & $38.2 \pm 4.5$ & $88.1 \pm 11.2$ & 0.002 \\
\hline $\begin{array}{l}<=3 \% \text { of the start value } \\
\text { at two sequential occasions }\end{array}$ & $55.9 \pm 10.0$ & $120.8 \pm 10.3$ & 0.0004 \\
\hline $\begin{array}{l}<=5 \% \text { of the start value } \\
\text { at first occasion }\end{array}$ & $39.8 \pm 4.7$ & $88.1 \pm 11.2$ & 0.002 \\
\hline $\begin{array}{l}<=5 \% \text { of the start value } \\
\text { at two sequential occasions }\end{array}$ & $70.3 \pm 12.2$ & $129.0 \pm 9.6$ & 0.001 \\
\hline $\begin{array}{l}<=10 \% \text { of the start value } \\
\text { at first occasion }\end{array}$ & $83.3 \pm 4.7$ & $96.3 \pm 11.8$ & 0.005 \\
\hline $\begin{array}{l}<=10 \% \text { of the start value } \\
\text { at two sequential occasions }\end{array}$ & $83.9 \pm 12.9$ & $144.4 \pm 5.8$ & 0.002 \\
\hline
\end{tabular}

* No statistics are computed because all cases are censored.

\section{ACKNOWLEDGEMENTS}

Supported by grants IGA NR 7825-3 Ministry of Health, and MSM 6198959216, Ministry of Education, Czech Republic.

This paper is dedicated to the memory of professor RNDr. Stanislav Komenda, DrSc. for his sophisticated and challenging solutions of scientific and human problems.

\section{REFERENCES}

1. Bland M. An introduction to medical statistics. Oxford University Press 2000.

2. Deiss D, Bolinder J, Riveline JP, Battelino T, Bost E, Tubiana-Rufi N, Kerr D, Phillip M. Improved glycemic control in poorly controlled patients with type 1 diabetes using real-time continuous glucose monitoring. Diab Care 2006; 29 (12): 2730-2732.

3. Faber E, Koza V, Vitek A, Mayer J, Sedlacek P, Zak P, Zapletalova J, Benesova K, Krejcova H, Steinerova K, Maresova I, Cetkovsky P. Reduced-intensity conditioning for allogeneic stem cell transplantation in patients with chronic myeloid leukemia is associated with better overall survival but inferior disease-free survival when compared with myeloablative conditioning - a retrospective study of the Czech National Hematopoietic Stem Cell Transplantation Registry. Neoplasma. 2007;54(5):443-6.

4. Gallo J, Langová K, Havránek V, Čechová I. Poor survival of ABG I hip prosthesis in younger patients. Biomed Pap Med Fac Univ Palacky Olomouc Czech Repub. 2008; 152(1):163-169.

5. Garg SK. Glucose Monitoring: An important tool for improving glucose control and reducing hypoglycemia. Diab Technol Therap 2008; 10 (1):1-4.

6. Hirsch IB, Amstrong D, Bergenstal RM, Buckingham B, Childs BP, Clarke WL, Peters A, Wolpert H. Clinical application of emerging sensor technologies in diabetes management: concensus guidelines for continuous glucose monitoring (CGM). Diab Technol Therap 2008;10(4): 232-246.

7. Chlup R, Jelenová D, Chlupová K, Zapletalová J, Chlupová L,
Bartek J. Function and accuracy of glucose sensors beyond their stated expiry date. Diab Technol Therap 2006;8(4): 495-504.

8. Chlup R, Peterson K, Zapletalová J, Langová K, Kudlová P, Přibylová $\mathrm{H}$, Matušková V. Relation between HbAlc and average one-month interstitial fluid glucose concentration (ISFG) determined by continuous glucose monitoring - preliminary results of an ongoing study. Diabetes 2007;56 (Suppl 1):A 527 (Abstract 2083-PO).

9. Chlup R, Rehořová J, Langová K, Zapletalova J, Kudlova P, Přibylová H, Peterson K, Bartek J, Slezáková L. Effects of twomonth consumption of selected foods with low/high glycemic index and anthropometric parameters in healthy persons (DEGIF V). Diabetes 2007;56(Suppl1):A688(Abstract).

10. Chlup R, Zapletalová J, Sečkař P, Chlupová L, Táncosová S, Rezníčková M. Benefits of insulin aspart vs phosphate-buffered human regular insulin in persons with type 1 diabetes treated by means of an insulin pump. Biomed Papers 2004;148(1): 27-32.

11. Chlup R, Peterson K, Kudlova P, Hucikova J, Zapletalova J, Novotny D. Vliv konvenčního a kontinuálního selfmonitoringu glykemie na vývoj koncentrace HbAlc u osob s diabetem léčených inzulinovou pumpou. Diabetes a obezita. 2008 (16):55-64.

12. Chlupová K, Kohnert KD, Heinke P, Augstein P, Chlup R, Salzsieder E. Resultate kontinuerlicher Glukosemessungen (CGMS) unter ambulanten Bedingungen zur Beurteilung der Stoffwechseleinstellung bei T2DM. Diabetologie und Stoffwechsel 2006;1 (1): 94(Abstract).

13. Jadviščoková T, Fajkusová Z, Pallayová M, Luža J, Kuzmina G. Occurence of adverse events due to continuous glucose monitoring. Biomed Pap Med Fac Univ Palacky Olomouc Czech Rep. 2007;151 (2): 263-266.

14. Kaplan EL, Meier P. Nonparametric estimation from incomplete observations. J Amer Statist Ass 1958; 53: 457 - 481.

15. Klein JP, Goel PK. Survival analysis: State of the Art. Kluwer Academic Publisher, Dordrecht, The Netherlands, 1992.

16. Köcher M, Černá M, Utíkal P, Kozák J, Šišola I, Bachleda P, Dráč P, Sekanina Z, Langová K.: Subintimální angioplastika ve femoropopliteální oblasti - střednědobé výsledky. Ces Radiol 2008; 62(2): 153-159.

17. Kudlová P, Chlup R. Selfmonitoring u osob s diabetem. Interní Med 2006;8(12): 539-544. 
18. Langová K. Survival analysis for clinical studies. Biomed Pap Med Fac Univ Palacky Olomouc Czech Repub. 2008; 152(2):303-307.

19. Martin S, Schneider B, Heinemann L, Lodwig V, Kurth HJ, et al. Selfmonitoring of blood glucose in type 2 diabetes and long-term outcome: an epidemiological cohort study. Diabetologia 2006;49: 271-278.

20. Mazze RS, Strock E, Borgman S, Wesley D, Stout P, Racchini MS. Evaluating the accuracy, reliability and clinical applicability of continuous glucose monitoring (CGM): Is CGM ready for real time? Diabetes Technol Ther 2009:11(1):11-18.

21. Mlčák P, Fialová J, Trnková K, Chlup R. A continuous glucose monitoring system (CGMS) - A promising approach for improving metabolic control in person with type 1 diabetes mellitus treated by insulin pumps. Biomed Pap Med Fac Univ Palacky Olomouc Czech Rep 2004;148: 33-38.

22. Pazin-Filho A, Kottegen A, Bertoni AG, Russel S D, Selvin E, Rosamond WD, Coresh: HbA1c as a risk factor for heart failure in persons with diabetes: the atherosclerosis risk in communities (ARIC) study. Diabetologia 2008;51:2197-2204.

23. Peterson K, Chlup R, Langová K, Zapletalová J, Kudlová P, Přibylová $\mathrm{H}$. Benefits of continuous glucose monitoring transmitted to Paradigm 722. Diabetes 2007; 56 (Suppl 1):A531 (Abstract 2099-PO)

24. Peterson K, Chlup R, Kudlova P, Slezakova L, Zapletalova J, Langova K, Doubravova B, Bartek J, Seckar P, Nakladalova M. Influence of oral antidiabetic drugs on hyperglycemic power of foods in persons with type II diabetes mellitus (DEGIF IV). Diabetes 2007; 56 (Suppl 1 ):A688 (Abstract).

25. Peterson K, Chlup R, Langová K, Zapletalová J, Kudlová P, Přibylová H. Benefits of Continuous Glucose Monitoring Transmitted to Paradign 722, Diabetes. 2007; 56(1): A531.

26. Peterson K, Zapletalova J, Kudlova P, Matuskova V, Bartek J, Novotny D, Chlup R. Benefits of 3-month continuous glucose monitoring for persons with diabetes using insulin pumps and sensors. Biomed Pap Med Fac Univ Palacký Olomouc Czech Rep. 2009; 153 (1):47-52

27. Pickup J, Keen H. Continuous subcutaneous insulin infusion at 25 years: evidence base for the expanding use of insulin pump therapy in type 1 diabetes. Diabetes Care 2002; 25: 593-598.

28. Procházka V, Trněný M, Pytlik R, Vasová I, Král Z, Belada D, Kozák T, Kubáčková K, Siffnerová $H$, Matuška M, Lysý M, Bolomská I, Petráková K, Otavová B, Přibylová J, Švecová J, Papajik T, Hamouzová M, Petrová M, Zapletalová J, Langová K. Peripheral T-cell lymphoma, unspecified - the analysis of the data from the Czech Lymphoma Study Group (CLSG) registry. Biomed Pap Med Fac Univ Palacky Olomouc Czech Repub. 2007; 151(1):103-7.

29. The Diabetes Control and Complications Trial Research Group. The effect of intensive treatment of diabetes on the development and progression of long-term complications in insulin-dependent diabetes mellitus. N Engl J Med 1993; 329: 977-986. 
